\title{
Dilemma of Modern Indian Bride: A Critical Analysis of Chetan Bhagat's One Indian Girl
}

\author{
Neeta Rawat \\ Research Scholar \\ Department of English \\ Mohanlal Sukhadia University \\ Udaipur, India \\ neeturawat7.nr@gmail.com
}

\begin{abstract}
In an advent of post-modern era; India is evolving as a new country in their lifestyle, career orientation, relationships, and many others. Like every other phenomena marriage system is also changing although the importance of marriage is still deeply down in Indians veins. In this period when technology is growing so fast and people are connected by means of cyber even though they are thousand miles away. The relationships are forming and breaking in this place and period simultaneously. One such relationship we also witness in this novel. In this present paper we will talk about the dilemma of a young Indian girl who is about to get married and what her mini-me tries to allude her to her inner self. In this paper we will analyze the hustle and bustle of marriage in Indian families. The story is all about Radhika Mehta, an investment banker at Goldman Sachs in New York. The whole story revolves around the protagonist 's life and marriage. Chetan Bhagat's keen projection of women's inner self is commendable in every sense; he displayed turmoil of Indian Bride in a comprehensive way that every Indian girl feels connected to Radhika's abeyance. This research paper's
\end{abstract}


ingenious effort is to bring in light all the aspects which makes Radhika to cancel her destination wedding.

Keywords: Modern Bride, Abeyance, Marriage, Turmoil and Love.

Introduction

Chetan Bhagat is one of the eminent Indian English writers. "Bhagat is the symbol of new India. A torch-bearer for an unafraid generation." He is India's leading figure in the field of literature. His books are translated globally and he was included among the 100 influential people in the world by Time Magazines. His stories are being adapted in Bollywood industry. He was an investment banker but he quit his job for full time writing; his passion for writing made him India's leading writer in history. His books work extra ordinary well in the Indian market. Chetan Bhagat's modern writing skills and his interest in displaying Indian scenario in this contemporary world is appreciated by readers all around the globe. His writing takes us to a new world which is free from the oppression and subjugation of women. Chetan Bhagat's writing skills make his readers feel empathetic and they feel connected gradually, the story goes. Chetan Bhagat is well known for his novels, Five Point Someone (2004), One Night @ Call Centre (2005), Two States (2009) and Half Girlfriend (2014). He chose a writing style which is different from other English literature he's a journalist and a youth icon. His stories feel like they're a replica of any Indian boy and girl; his books are more appealing to youth. He's the most read and popular writer among the youth of India. He's the best-selling writer in India. His books are read worldwide and also get applause.

In the present paper we are analyzing Chetan Bhagat's One Indian Girl. We are proceeding with textual investigation as a mode of study and we will move ahead by using qualitative methods. This paper shows how indecisive it is for a head-strong independent girl to tie a knot with the man that she hardly knows, and what are the factors that put her in situations where she refuses for her marriage on a wedding day. In this study we nuances the 
life of Radhika Mehta, the protagonist of the story. Radhika is an intelligent girl. Since her childhood, Radhika has been good at studies; she's a topper and she realizes that she's only good at academics "I topped my class at age twelve, and won the Maths Olympiad at age thirteen".(OIG7). She is not like those girls who only think about their looks, figures, and boys; rather, she's someone who prioritizes her career. Radhika completed her MBA and got a job in New York as an Associate at Goldman Sachs. She has a bright shining present and lives a life full of joy abroad. Chetan Bhagat portrayed Radhika likely as him; he lived in Delhi, was an investment banker and went to Hong Kong; he sketched her picture like his journey in life.

Although we are living in patriarchal dominance and women's exploitation, this book doesn't indicate such things; rather, we find women at the front foot of the story." My mother looked at my father, a level-two glare. It signified: 'Will you ever take the initiative".(OIG1). Chetan Bhagat projected her heroin as a mature, sensible and minded girl, who only focuses on her work and how to earn good money. Mehta sisters are very differently showed in the story, Radhika's elder sister Aditi is all feminine in her attributes; she loves dressing up in a feminine way, makeup and know-how to impress boys; she married her boyfriend and became a happy housewife. She has to do nothing with the job and career in her life. Radhika is all opposite to her; she's passionate and a career-oriented girl. Radhika's mother worried about her marriage the year after her job, but more than that she was worried about people; she's very conscious about their Mehta's reputation in society "Mom, why are you obsessed with me getting married?"(OIG193).

This present paper proposes how, even after being a successful money making independent girl, Radhika was tied in a manacle of family's desire of getting married. Radhika was happy with her work; she was travelling all around the world and cracking great business deals. She's not even interested in a marriage conversation with her mother, who 
kept insisting on her to meet boys or making profiles on matrimonial sites. Radhika resists and tries to make her mother understand that she doesn't want to marry; she's happy in her job and not thinking about a marriage but her mother was always worried what people would say why Mehta's daughter is not getting married. Is there something wrong with her. Parents think more about society and those so-called people who don't even exist in the world. Chetan Bhagat is one such writer who knows what lies within India's youth when it comes to marriage. He brilliantly put forward this psyche of a youngster, why parents don't understand us?. He has clearly shown this in his writing.

In New York, Radhika started dating Debashish and finds comfort in the relationship; soon they came to a living relationship. When Radhika asked him what's the future of their relationship and where it is going to last long, then, he refused to take responsibility by saying he wants to focus on his career right now and not going to think about marriage. He clearly said to Radhika. She has to make her parents understand. Radhika is more accomplished in her work whereas Debashish is still struggling with his office politics. She earns more than him, and while getting promotions and bonuses, her inner desire wants acknowledgment from him. "Still I want Debu to also acknowledge it. why? Why do we girls have this defect?".(OIG80). Radhika wants to marry Debu but he's always in his work and in a denial mode. She kept explaining to him they were not going to marry tomorrow, but at least she had to tell her parents that she had someone in my life so that they would not knock everybody's door for the son-in-law, but Debashish was ignorant of her turmoil or either he don't wanted to get into it. Debu wanted her to quit the job; he wanted his future wife to be a homemaker. He thinks women who's successful and earn much maybe she wouldn't be a good mother as if she didn't give much time to their kids " But I want my kids' mother to be at home for them"(OIG96). Radhika is as emotional and in-loved with him as any Indian girl does, but she's strong and didn't want to affect her career because of her personal reasons. 
Chetan Bhagat represented a strong headed, career-oriented Indian woman, who knew how to deal with their matters and not to intermingle personal and professional life.

Chetan Bhagat through his work mirrored contemporary India, in which both men and women are equally passionate about their career and have freedom to live life the way they want. Debashish broke up with Radhika by saying I want simple Indian girl, " You are not an easy person to be with...I want to break up".(OIG101). This devastated Radhika from inside, even though she's so successful, earning more than a manager in an Indian bank but she still questioned herself; am I not a marriage material or am I not fit for someone to be loved?. It became difficult for her to be in that city which only meant Debu for her "I couldn't imagine this city without Debu".(OIG103). She decided to leave the city and job, too. Chetan Bhagat shows her reader the in-depth feelings of his protagonist and the broken piece inside her which she carries with her to her new workplace, Hong Kong. He portrayed Radhika's inner self in a way that it could be hard to believe that this much deep insight is displayed by a male author.

Gathering all her courage, Radhika started her new life in Hong Kong. Debu's memories haunted her sometimes, but she made herself firm. Chetan Bhagat in carving his story makes love play a major role in Radhika's life. Where she feels helpless in love at one point, another side because of a heartbreak, she makes herself strong enough to move on in her life. In Hong Kong Radhika meets Neel, after knowing about his marriage and having two kids; still Radhika gets attracted and started feeling for him. Soon she realizes nothing will come out of this relationship; she's intertwined her personal and professional life, which bothers her to the next extent; she quits that job, too, and moves to London. At one point in our life we know what's good for us and what we should do now but don't know for what we wait for so long, maybe because we are aware of our human nature that in some circumstances of life we need a partner to be loved and be by our side. 
Radhika is a blunt, straight-forward girl; she's not submissive and not much liked by aunties for their sons. Her mother always kept saying to her, why can't you be like your sister, a homely type. Radhika is a different girl who has high aspirations in life and who not only was born with the dream of getting handsome man as her husband. She thought guys didn't like her because she's not so fair and more successful than them and she might have lived and stayed single in her life. Her mother kept insisting on her to marry otherwise after thirty she will not find suitable suitors; she made Radhika's profile on matrimonial site; however she's not at all interested in that but for mother's happiness she showed her consent.

Radhika is a modern girl, full of life. She lives her life to the full extent, travels half the world, drinks, and smokes. She herself feels she doesn't fit in with the image of a cultured Indian daughter-in-law. "Smoking up on the beach her wedding. It's not what good Indian bahu do".(OIG137). Radhika is a straightforward, open minded girl; she doesn't sugar coat her sentences to please people. She earns a lot and feels free to speak. According to her, she might not be too likable by people because in this patriarchal society women should speak less, and behave like women, but Radhika was different. After a long inner conflict, Radhika stopped all her opinions regarding her feelings about marriage. On a matrimonial site, Mehta finds the perfect match for her daughter. Radhika's mother kept emphasizing to her that she should marry now. She finds Brijesh Gulati, the perfect suitor for her girl, a US -based job, a well-settled nice guy, and intones her to say yes "No prince on a horse will come"(OIG235). Radhika took a long sigh and finally said yes to the proposal. The reverberating mini-me inside Radhika kept inkling her to rethink what she was doing.

In the story, Mehta and Gulati's family planned to do their children's destination wedding in Goa. Destination weddings are kind of a new vogue of this era. People are enjoying this new trend and it can also be called the trend of a new way in which it becomes possible to mingle with people from other sides. In Indian marriages, bride's family are under 
pressure to make everything best as per groom's house wants. "Beta, these are the norms. She don't understand. We have to keep them comfortable. Girls' side is expected to adjust".(OIG4). There is no sense of equality in between the families. Exclusive treatment is given to groom's family to make them feel special in every sense. A sort of mental pressure is there in Bride's house. Radhika's mother roars in fury, when she comes to know that the arrangements are not proper. "It's my daughter's wedding. Are you going to shame us? ".(OIG1). When Mehta family didn't get enough rooms as per demand, they started panicking that they could not have done good arrangements for groom's family. Kamla Bua in a taunting way said why you wanted marriage in Goa, to waste money Delhi is also a nice place with huge marriage hall and good facilities. The author beautifully weaves those tiny incidents in a way that Indian reader feels they are actually at an Indian wedding. This is something commendable and appreciable quality of a writer to make his reader feel empathetic.

As an Indian author Chetan Bhagat beautifully project Indian family and all the hustle and bustle that happens in marriages. All the melodrama of fufa and buaa in marriages are well portrayed by Chetan Bhagat. Chetan Bhagat in weaving his storyline, displayed her women characters on the front foot. Whether it Aparna Mehta Radhika's mother or Kamla Bua, shows his Indianness by beautifully carving Mrs. Mehta's character.

Throughout her wedding days, Radhika was pretending to be a well-mannered and a cultured girl and trying to behave like a would-be bride behaves among people, a pre notion that exist in society just to entertain crowd around her and she kept talking with her mini-me why she's doing all these things. Radhika's parents and relatives are happy and excited for her marriage, after all it's a destination wedding in Goa, but she looks confused at her wedding. She does not know what's happening and what she's doing to her life. The dilemma of the Indian bride. It's there in Indian families that they want their daughter to be in salwar- 
kameez to make her look appealing to groom's family but Radhika is a new Indian girl; she doesn't believe in these customs, she questioned pre existing notions of society "Why am I expected to doll up?"(OIG5). Radhika is an independent and modern girl, like every bride, she also wants to do things her way; after all it was her day to shine. but this is not possible in Indian marriage system when our family rigorously follows all the set Indian rituals.

Radhika's past is no bygone; rather pops up on that day when she's going to tie a knot of marriage with Brijesh Gulati. Lately Debashish realizes Radhika's importance in his life; he comes with an apology; he tries to convince her that he realizes all his mistake and wants to marry him now, her wedding will not be cancelled, rather only groom will change and everything will be alright."Please baby. Please, I beg you, 'Debu said. 'I have come all the way from New York".(OIG118). Is it so easy for a girl to take such a decision, but for Debu it's merely a step that has to be taken, but for Radhika it was her life-changing words. "Stop this wedding. Tell your parents".(OIG242). Why would a girl believe such a guy who ditched her in the past. We find little feminist side to Radhika as she keeps talking about equality and wants her to be treated as equal as male. Whether when she breaking up with Debu and expecting him to respect her success or money, and when she and Brijesh spend night in lockup and all the fingers are pointing toward her because she's a girl and no one want such a daughter-in-law who drugs, smoke and spent night in a lockup before her wedding day.

The second tragic thing that happened to Radhika on her wedding week. Neel, at her sangeet function, pops up and confesses his love for her and apologizes for her past mistake and tries to convince her to come back in his life as he filed divorce with her wife. " Radhika Mehta, I love you and will always do. Will you marry me?"(OIG240). Radhika in a distress situation, tries to figure out what's happening with her, when she really wanted Debu to be her side and tried every possible thing than he leaves her alone in the New York and when 
she gets attracted to ten year elder man Neel in the office; she backs off because she doesn't want to be called a home breaker. When she tries to move on from all this in her life, and makes up her mind to tie a knot of marriage with Brijesh, than she gets stuck in these unwanted circumstances. "Both of you are here to stop my wedding, which is in few hours...you have put me in quite a predicament".(OIG256). She's in the confused state of mind about what suddenly happens to these guys who appear in her marriage and suddenly realizes that she's perfect and the only match for them. She feels disheartened, where were these guys when she's pleading with them for their relationships.

Radhika sees happy faces around her, dancing, and enjoying herself. She questioned, why people search for the reason to enjoy or to be happy, why someone has to marry to give them a reason to cheer up "Why does one have to get married to have so much fun? Why can't extended families just get together once in a while and dance for no reason".(OIG249). At her own wedding she's not happy, after doing lots of expense and having that much crowd at her wedding she won't be able to figure out with whom she should live her life Debu, Neel or Brijesh. Her inner self helps her to come out of this abeyance by making her realize that marriage is not something that we do to please others, she also deserves to be happy in her life if she doesn't want this mess in her life then she should take control of it. That's a determined Radhika was. Radhika called up all the three guys Neel, Brijesh and Debu, to clear things up them between them; she didn't want to be in problematic circumstances any more. Women inside Radhika spoke hardly; women wanted their career and family too. There is no such choice ever exists that when have to be made between the two. "We don't want to choose. We want to fly and we also want a beautiful nest".(OIG259). Radhika clearly put her dilemma in front of both men. Women should not be put in such an abeyance where they have to choose either to fly high or sit at home. In this patriarchal society women have to balance their family and work; why does society not keep such expectations from men. 
Radhika clear, and loud, confronts Debu. How hypocritical he is. He talks about women's growth and career, but in real life he's a narrow-minded jealous man who cant's see women earning more than him. Women could fly high but not higher than men. He can't take her success. She snapped at his face. Whereas Neel was far sensible and mature than Debu, Radhika knew what kind of girl Neel wanted, a young career-oriented party girl who would make him feel youthful, but soon this was going to last. As a woman Radhika also wants family and kids, after that. She doesn't want to compromise with her desire to live life moiety. She rejected both boys. Radhika is not even sure about her marriage with Brijesh and she refuses to marry Brijesh too "I can't get married to you today".(OIG261).

Radhika knows something wrong is happening in her life and she has to figure it out for her own sake. She's not well prepared for marriage. The marriage was enforced on her; she thought she would cope up with it, but till her wedding day she was in turmoil as to how to vanish from this whole mess. "But I am not in the present either. I am nowhere, really. I need to find myself".(OIG262). Marriage is part of the mundane; even today its value and purity remains. She's a sagacious girl who understands the sanctity of marriage; marriage is something which is performed from both sides. If she's not well prepared for that, how will she grip the knot of marriage. While gaining consciousness she takes the decision of cancelling marriage, although she knows the consequences, but this time she sticks to her mind.

\section{Conclusion}

Chetan Bhagat showed nuanced Indianness in her books. He doesn't go with the flow to represent India with oppression and hollowness; No liberty for women to speak or to fulfill their dreams; he, with his own unique style, showcase new India, new Indian women in this twenty first century that's why Chetan Bhagat is known as author of youth and loved by them. He highlights that segment of life which is crucial so each one of us should think and rethink 
before making decisions. Marriage and family pressure put Radhika in such turmoil where she was left confused, but after gaining self-actualization she stood up loud and clear for herself. 


\section{Works Cited}

Bhagat, Chetan. One Indian Girl. New Delhi, Rupa Publication, 2016, pp.272.

"Chetan Bhagat." Wikipedia, 12 Dec.2021, https://en.wikipedia.org/wiki/Chetan_Bhagat Juyal, Rachna. "The Author Of Modern Era 'Chetan Bhagat: The Illustrious Genre, Perspective, Style And The Aspect Of Future Research". Journal Of Emerging Technologies And Innovative Research, vol. 5, no. 7, 2018, pp. 878-879. JETIR, https://www.jetir.org/view?paper=JETIR1807856. Accessed 11 Dec 2021.

Purie, Aroon. "Chetan Bhagat's Forthcoming work of fiction." India Today, 29 August 2019, https://www.indiatoday.in/magazine/editor-s-note/story/20140908-india-today-editorin-chief-aroon-purie-on-chetan-bhagat-forthcoming-work-of-fiction-805102-2014-0829. Accessed 2 Dec 2021.

Ramasamy, Ragupathi. "Breaking Gender Stereotype: Women of India in Chetan Bhagat's One Indian Girl - A Study". Journal Of Emerging Technologies And Innovative Research, vol. 6, no. 5, 2019, pp. 278-283. JETIR, https://www.jetir.org/papers/JETIR1905E43.pdf. Accessed 8 Dec 2021. 